\title{
Carbon dioxide dynamics and fluxes in coastal waters influenced by river plumes
}

\author{
W.-J. Cai, C. T. Arthur Chen, and A. Borges
}

\section{Introduction}

Globally, estuaries are a source of $\mathrm{CO}_{2}$ to the atmosphere, releasing a significant fraction of $\mathrm{CO}_{2}$ that the terrestrial biosphere absorbed from the atmosphere, and thus significantly reduce riverine terrestrial carbon fluxes to the ocean. Although several recent synthesis papers brought the flux lower from $\sim 0.5$ to $\sim 0.25 \mathrm{Pg} \mathrm{C} \mathrm{yr}^{-1}$ (Table 7.1), the flux is still quite significant in consideration of global carbon budget and pathways. Most importantly, the likely uncertainty in estimating air-water $\mathrm{CO}_{2}$ flux in coastal waters and wetlands is so large $\left( \pm 0.2 \mathrm{Pg} \mathrm{C} \mathrm{yr}^{-1}\right)$ that it becomes a major obstacle for a precise assessment of the $\mathrm{CO}_{2}$ flux at the air earth interface (be it terrestrial or ocean), thus making the effort for further improving the accuracy of estimating air-earth surface $\mathrm{CO}_{2}$ exchange fluxes less meaningful for climate change research - if such uncertainty in coastal systems is not tackled (Cai 2011).

Previous works have largely focused on inner estuaries within coastal shorelines, and river plumes extending outside the shorelines largely are ignored for a number of reasons. Most importantly, river plumes are not limited geographically, and their areas are not defined clearly. They also have $\mathrm{CO}_{2}$ values closer to saturation with respect to the atmosphere. These properties are in stark contrast to inner estuaries, which are geographically limited by river banks or shorelines and virtually in all cases have $\mathrm{CO}_{2}$ values distinctly higher than the atmosphere. Hence river plumes are difficult to quantify and generalize in terms of an annual exchange flux of $\mathrm{CO}_{2}$ with the atmosphere. River plumes also reside directly on the continental shelves and thus often are included as part of shelves in global syntheses. Freshwater plumes of some large rivers (e.g., Amazon, Congo, Niger) often even extend beyond the continental shelf into the continental slope and ocean basin (Bianchi and Allison 2009). Because of the lack of reliable air-water $\mathrm{CO}_{2}$ flux estimates and the absence of global estimates of surface areas, river plumes have not been included in previous syntheses of global coastal water $\mathrm{CO}_{2}$ fluxes (Borges 2005; Borges et al. 2005; Cai et al. 2006; Chen and Borges 2009; Laruelle et al. 2010).

This chapter first briefly reviews the state of knowledge of global (inner) estuarine $\mathrm{CO}_{2}$ flux and the existing problems. Then, we describe the distribution features of $\mathrm{CO}_{2}$ parameters in and around large river plumes over continental shelves to discuss factors that control $\mathrm{CO}_{2}$ distribution in areas dominated by river plumes. We also attempt to estimate air-sea $\mathrm{CO}_{2}$ flux in river plumes globally and provide a general view on whether inclusion of river plume in the estuarine $\mathrm{CO}_{2}$ flux assessments would change the currently best known global estuarine $\mathrm{CO}_{2}$ flux values. 
Table 7.1. Global $\mathrm{CO}_{2}$ degassing fluxes from inner estuaries to the atmosphere. Here inner estuaries are defined as estuarine areas within shorelines. A positive sign indicates ocean $\mathrm{CO}_{2}$ loss (degassing) and a negative sign indicates ocean $\mathrm{CO}_{2}$ uptake (in-gassing)

\begin{tabular}{|c|c|c|c|c|}
\hline & $\begin{array}{c}\text { Flux } \\
\mathrm{molC} / \mathrm{m}^{2} / \mathrm{yr}\end{array}$ & $\begin{array}{c}\text { Area } \\
10^{6} \mathrm{~km}^{2}\end{array}$ & $\begin{array}{c}\text { Flux } \\
\mathrm{PgC/yr}\end{array}$ & Reference \\
\hline Estuaries & 35.71 & 1.40 & 0.6 & $\begin{array}{l}\text { Abril and } \\
\text { Borges } 2004\end{array}$ \\
\hline Estuaries & 38.12 & 0.94 & 0.43 & Borges 2005 \\
\hline Salt marshes & 23.45 & 0.14 & 0.04 & \\
\hline Mangroves & 13.66 & 0.20 & 0.04 & \\
\hline Total & 33.2 & 1.28 & 0.51 & \\
\hline Estuaries & 28.62 & 0.94 & 0.32 & Borges et al. \\
\hline Salt marshes & 21.4 & 0.14 & 0.036 & 2005 \\
\hline Mangroves & 18.66 & 0.15 & 0.033 & \\
\hline Total & 26.42 & 1.23 & 0.39 & \\
\hline Estuaries & 32.1 & 0.943 & 0.36 & Chen and \\
\hline Salt marshes & 30.4 & 0.384 & 0.09 & Borges 2009 \\
\hline Mangroves & 27.1 & 0.147 & 0.05 & \\
\hline Total & 28.27 & 1.474 & 0.50 & \\
\hline Small deltas and estuaries & 25.7 & 0.084 & 0.026 & Laruelle et al. \\
\hline Tidal systems and embayments & 28.5 & 0.276 & 0.094 & 2010 \\
\hline Lagoons & 17.3 & 0.252 & 0.052 & \\
\hline Fjords and fjärds & 17.5 & 0.456 & 0.096 & \\
\hline Total & 21.0 & 1.067 & 0.268 & \\
\hline $\begin{array}{l}\text { Estuaries (both } \\
\text { river-dominated and } \\
\text { nonriverine coastal lagoons) }\end{array}$ & 20.83 & 1.05 & 0.25 & Cai. 2011 \\
\hline Estuaries & $23.9 \pm$ & 1.07 & 0.26 & $\begin{array}{l}\text { Chen et al. } \\
2012\end{array}$ \\
\hline
\end{tabular}

Note: Here inner estuaries are defined as estuarine areas within shorelines. A positive sign indicates estuarine $\mathrm{CO}_{2}$ loss (degassing) and a negative sign indicates estuarine $\mathrm{CO}_{2}$ uptake (in-gassing).

\section{2. $\mathrm{CO}_{2}$ degassing flux in inner estuaries}

It has long been known that inner estuaries act as sources of $\mathrm{CO}_{2}$ to the atmosphere (Park et al. 1969) because of their net ecosystem metabolic status being heterotrophic (Odum and Hoskin 1958; Smith and Hollibaugh 1993; Hopkinson and Smith 2005; Borges and Abril 2011). However, it was not until the late 1990s that a regional synthesis of fluxes of $\mathrm{CO}_{2}$ out of the estuaries was made available by Frankignoulle et al. (1998), who reported that $\mathrm{CO}_{2}$ emissions from inner estuaries in Europe (average $50 \mathrm{~mol} \mathrm{~m}^{-2} \mathrm{yr}^{-1}$ ) was a significant term in the regional $\mathrm{CO}_{2}$ budget, equivalent to $5-10 \%$ of the total anthropogenic $\mathrm{CO}_{2}$ emissions from western Europe. The first compilation of global inner estuarine fluxes of $\mathrm{CO}_{2}$ was that of Abril and Borges (2004) and was based on only a handful of data. The datasets (Borges 2005; Borges et al. 2005) grew gradually, and in 2009 an assessment including 32 estuaries was published (Chen and Borges 2009). This database has been further extended to 60 inner estuaries in 2010 (Laruelle et al. 2010) and 106 inner estuaries in 2012 (Chen et al. 2012). 
Although the numbers of inner estuaries included in the $\mathrm{CO}_{2}$ flux estimation have increased in recent years, all global extrapolations have relied on the surface areas of inner estuaries - roughly estimated four decades ago by Woodwell et al. (1973), with the exception of a recent publication by Laruelle et al. (2010), which based extrapolations on typology (Dürr et al. (2011). The Woodwell et al. (1973) global estimate of surface areas of estuaries was based on the extrapolation of the estuarine area to coastline length for the United States that was extrapolated to the global coastline length. Surprisingly, these two estimates are rather close: $0.94 \times 10^{6} \mathrm{~km}^{2}$ by Woodwell et al. (1973) when intertidal areas (marshes and mangroves) are excluded and $1.10 \times 10^{6} \mathrm{~km}^{2}$ by Dürr et al. (2011). The Dür et al. (2011) typology is based on a geographical information system approach and also provides surface area estimates by estuarine types. Thus their approach was a major improvement for scaling of $\mathrm{CO}_{2}$ fluxes, because it was known that carbon was transformed differently according to estuarine types. For example, recent comparisons have been made between stratified fjords and wellmixed macro-tidal estuaries (Borges 2005) and stratified and well-mixed lagoons (Koné et al. 2008). Laruelle et al. (2010) scaled up the inner estuarine $\mathrm{CO}_{2}$ fluxes using the following four estuarine types: small deltas and estuaries ( $8 \%$ of total surface), tidal systems and embayments ( $26 \%$ of total surface), lagoons ( $24 \%$ of total surface), and fjords and fjärds ( $43 \%$ of total surface).

More recent studies, compiled in Table 7.1, appear to show a convergence of a water-to-air flux of $\sim 0.25 \mathrm{PgC} \mathrm{yr}^{-1}$ for the global inner estuaries. However, there are still large uncertainties, as many field expeditions have reported insufficient spatial and temporal coverage and were conducted under highly variable wind mixing and stratification conditions of the water column. The amount of data seems to focus mostly on the upper sections of inner estuaries, which are generally higher in $p \mathrm{CO}_{2}$. The lower inner estuaries, generally lower in $p \mathrm{CO}_{2}$, are relatively poorly covered, and the river plumes outside of shorelines are even less studied. Furthermore, coastal estuaries with little freshwater input and surrounded by wetlands generally have lower $\mathrm{CO}_{2}$ than those of river-dominated systems and have largely been understudied (Borges 2005; Jiang et al. 2008; Cai 2011). There has also been recent controversy on whether the large $\mathrm{CO}_{2}$ degassing flux in these systems is the result of decomposition of riverine terrestrial organic carbon, or is largely supported by lateral transport from adjacent productive coastal wetlands (Cai 2011). As several recent synthesis papers have discussed $\mathrm{CO}_{2}$ degassing flux in inner estuarine areas in detail, we refer readers to the literature cited in Table 7.1 and focus next on $\mathrm{CO}_{2}$ distributions, fluxes, and control mechanisms in river plumes in this chapter.

Frankignoulle et al. (1998) reported air-water $\mathrm{CO}_{2}$ fluxes in several European river plumes and emphasized that river plumes were characterized by air-water $\mathrm{CO}_{2}$ fluxes with fluxes being one to two orders of magnitude lower than inner estuarine regions. The river plumes they had studied were, however, limited to rivers of relatively low discharge and had data with little seasonal coverage. On the other end of the spectrum, several studies have provided an estimate of the $\mathrm{CO}_{2}$ sink of the Amazon River plume and estimated the overall sink in the plume from an extrapolation based on the relationship between the partial pressure of $\mathrm{CO}_{2}\left(\mathrm{CCO}_{2}\right)$ and salinity (Ternon et al. 2000; Körtzinger 2003; Cooley et al. 2007; Lefèvre et al. 2010). Additional data have shown that the relationship between $p \mathrm{CO}_{2}$ and salinity in the Amazon is remarkably stable on a seasonal basis (Lefèvre et al. 2010). Seasonal $\mathrm{CO}_{2}$ distributions and air-water fluxes in inner estuaries and river plumes have also been reported for the Changjiang River (Wang et al. 2000; Chen et al. 2008; Chou et al. 2009b; Zhai and Dai 2009) and preliminarily for the Mississippi River (Cai 2003; Dagg et al. 2005; Lohrenz and 


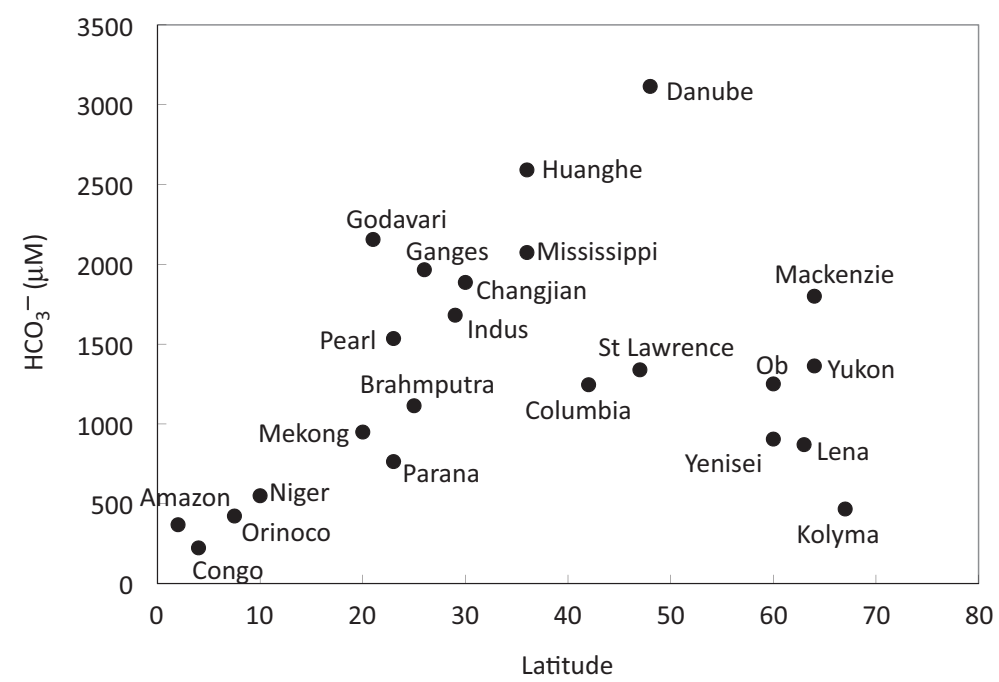

Figure 7.1. Latitudinal distribution of river bicarbonate $\left(\mathrm{HCO}_{3}{ }^{-}\right)$concentrations. Note that an average latitude value for each drainage basin was assigned to each river. Modified after Cai et al. (2008).

Cai 2006; Lohrenz et al. 2010; Huang 2013). However, the aforementioned information has not been properly incorporated in the global synthesis shown in Table 7.1; an initial attempt is made here to address this problem.

\section{Distribution pattern of $p \mathrm{CO}_{2}$ in river plumes and control mechanisms}

\subsection{River carbonate contents and the associated buffering capacity changes during river-ocean mixing}

Several chapters of this book have discussed the physical and biogeochemical properties of larger river plumes (e.g., Chapter 3), including the Mississippi and Atchafalaya River plumes (e.g., Chapter 18), the Changjiang plume (e.g., Chapter 10), the Pearl River plume (e.g., Chapters 11 and 13), and the Mekong River plume (e.g., Chapter 12). Thus, in this chapter we avoid repeating much of the background information provided in these other chapters. Here, we focus on surface water $p \mathrm{CO}_{2}$ distribution and air-sea $\mathrm{CO}_{2}$ flux from a few studied plumes and discuss the relationships between physical and biogeochemical properties of the plumes.

Middle-latitude and subtropical larger rivers (e.g., the Mississippi, Changiiang, and Pearl Rivers) typically have high bicarbonate $\left(\mathrm{HCO}_{3}{ }^{-}\right)$concentrations and fluxes because of abundant distribution of carbonate minerals in their drainage basins, in contrast to tropical larger rivers with low $\mathrm{HCO}_{3}{ }^{-}$concentrations, such as the Amazon and Orinoco Rivers (Cai et al. 2008; Cai et al. 2010). Thus $\mathrm{HCO}_{3}{ }^{-}$concentrations in the world's largest rivers do show a distinct latitudinal distribution (Fig. 7.1). Regardless of the particular latitude, river total alkalinity (TAlk) values and dissolved inorganic carbon (DIC) concentrations were generally lowest during peak river discharge and highest 

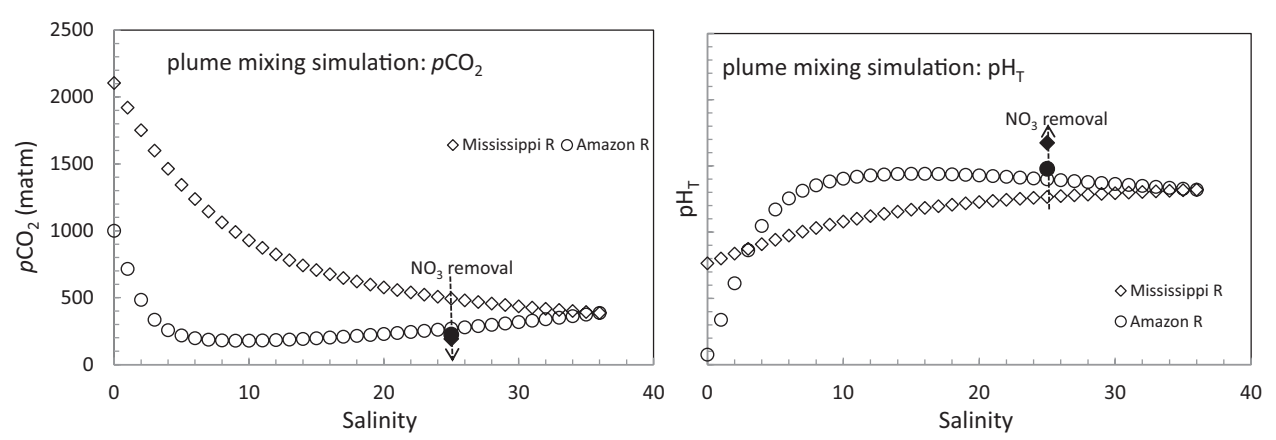

Figure 7.2. Predicted $p \mathrm{CO}_{2}$ and $\mathrm{pH}$ changes during plume mixing for a high carbonate river example (e.g., the Mississippi River) and a low carbonate river example (e.g., the Amazon River) during summer (assuming $\mathrm{T}=28^{\circ} \mathrm{C}$ ). Average TAlk values of the Mississippi River and Amazon River were estimated to be $2,300 \mu \mathrm{mol} \mathrm{kg}{ }^{-1}$ and $300 \mu \mathrm{mol} \mathrm{kg}^{-1}$, respectively. We also assumed a DIC $=$ TAlk + $30 \mu \mathrm{mol} \mathrm{kg}^{-1}$ (Guo et al. 2012) for both rivers, which results in reasonably expected values of $p \mathrm{CO}_{2}$ during summer. A complete removal of $\mathrm{NO}_{3}{ }^{-}$(arbitrarily set to occur at $\mathrm{S}=25$ ) leads to $p \mathrm{CO}_{2}$ as low as $192 \mu \mathrm{atm}$ and $\mathrm{pH}$ as high as 8.34 in the high carbonate river plume $\left(\left[\mathrm{NO}_{3}{ }^{-}\right]=100 \mu \mathrm{mol} \mathrm{kg}^{-1}\right.$,

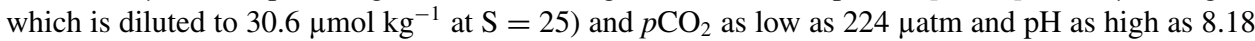
in the low carbonate river plume $\left(\left[\mathrm{NO}_{3}{ }^{-}\right]=15 \mu \mathrm{mol} \mathrm{kg}-1\right.$, which is diluted to $4.6 \mu \mathrm{mol} \mathrm{kg}^{-1}$ at $\mathrm{S}=25$ ). Observed extreme $p \mathrm{CO}_{2}$ and $\mathrm{pH}$ in the Mississippi River plume are similar to the simulations (Guo et al. 2012; Cai unpublished).

during lowest discharge, owing to the dilution effect of weathering products (Cai 2003; Cai et al. 2008; Chen et al. 2008; Bouillon et al. 2012; Guo et al. 2012).

High $\mathrm{HCO}_{3}{ }^{-}$content in subtropical to middle-latitude large river waters provides a high acid-base buffering capacity, comparable to that of seawater. For example, the TAlk and DIC concentrations of the Mississippi River are higher than or close to its ocean end-member. Thus $p \mathrm{CO}_{2}$ and $\mathrm{pH}$ changes are expected to be relatively small during their initial stage of mixing with seawater (Fig. 7.2). In sharp contrast, low carbonate river waters in tropical zone have little buffering capacity, and their $p \mathrm{CO}_{2}$ and $\mathrm{pH}$ values are quickly dominated by seawater (i.e., as shown with a rapid decrease in $p \mathrm{CO}_{2}$ and increase in $\mathrm{pH}$ in the Amazon River plume, Fig. 7.2). Therefore, the rapid $p \mathrm{CO}_{2}$ decrease to a minimum (or $\mathrm{pH}$ increase to a maximum) observed in many middle-latitude river plumes (Zhai and Dai 2009; Guo et al. 2012) cannot be attributed simply to thermodynamic changes during riverocean mixing as was presented in Salisbury et al. (2008). Large rivers in middle-latitudes are also rich in nutrients derived from use of agriculture fertilizers and sewage. Thus coastal waters receiving inputs from large rivers generally have very high biological production rates (i.e., eutrophication). As a result, $p \mathrm{CO}_{2}$ (or $\mathrm{pH}$ ) in these river plumes are expected to be very low (or high) (Fig. 7.2); such low $p \mathrm{CO}_{2}$ and high $\mathrm{pH}$ values have been observed in the Mississippi (Guo et al. 2012) and Changjiang River plumes (Chou et al. 2009b; Zhai and Dai 2009; Tseng et al. 2011). Consequently, we suggest that although ocean acidification, which has been linked with $\mathrm{CO}_{2}$ uptake from the atmospheric (which has increased because of fossil fuel use), has become a major ocean environmental stressor, eutrophication-induced $\mathrm{pH}$ increases are a dominant feature in surface water $\mathrm{pH}$ in the nutrient-rich river plumes worldwide (Borges and Gypens 2010). However, abundant organic matter exported to 
February

(A) $114^{\circ} \mathrm{E} \quad 117^{\circ} \mathrm{E} \quad 120^{\circ} \mathrm{E} \quad 123^{\circ} \mathrm{E} \quad 126^{\circ} \mathrm{E} \quad 129^{\circ} \mathrm{E}$

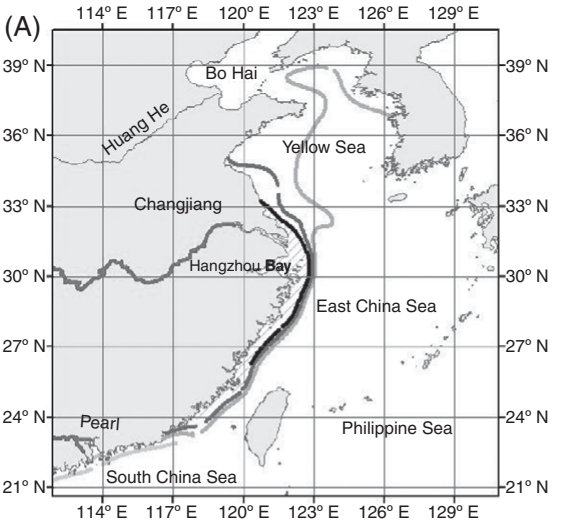

August

(C) $114^{\circ} \mathrm{E} \quad 117^{\circ} \mathrm{E} \quad 120^{\circ} \mathrm{E} \quad 123^{\circ} \mathrm{E} \quad 126^{\circ} \mathrm{E} \quad 129^{\circ} \mathrm{E}$
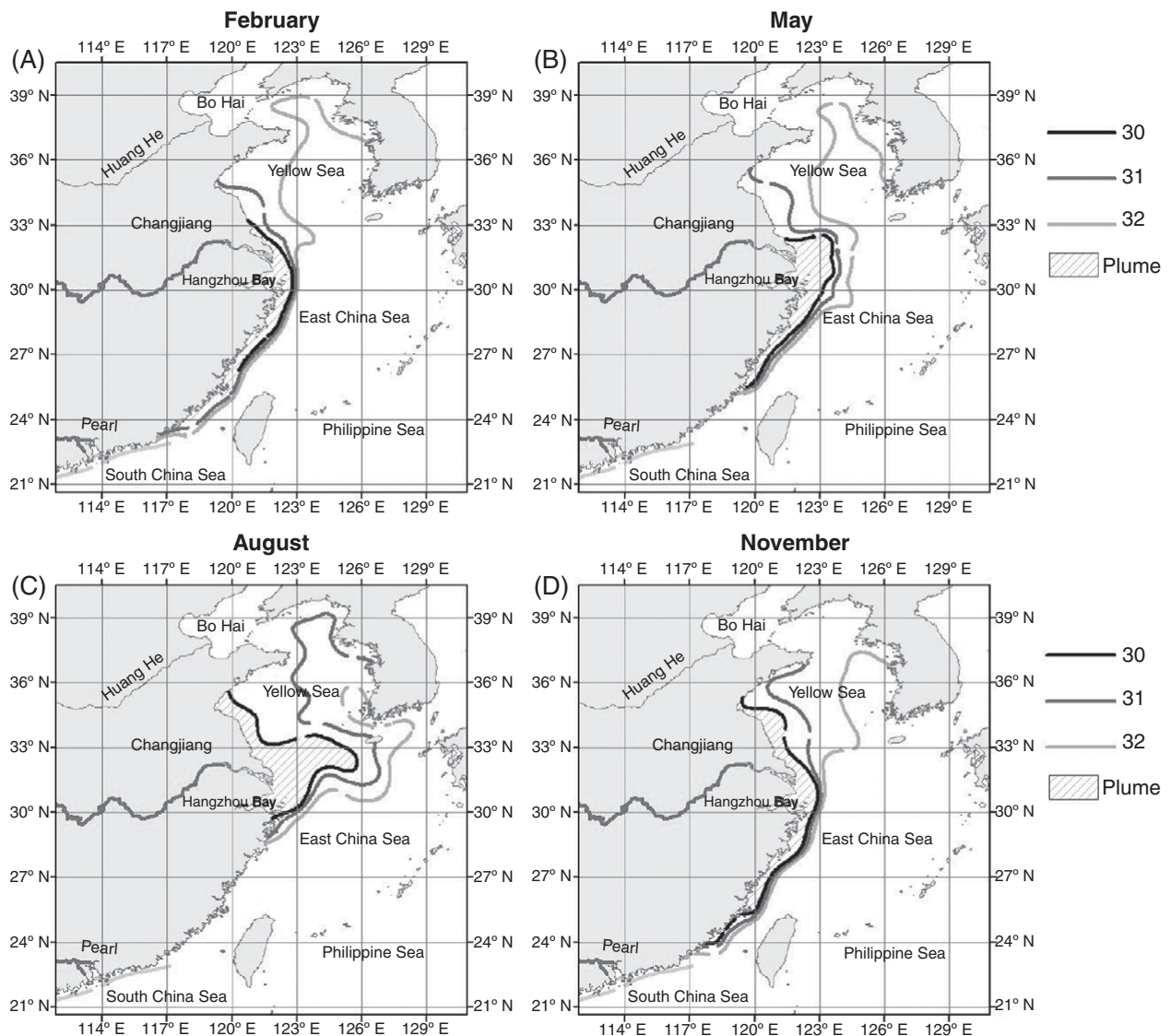

Figure 7.3. The Changjiang River plume in low-discharge February and high-discharge August from Kang et al. (2013). The river plume area was extracted by way of a geographical information system based on data from the Marine Atlas of the North China Sea-Hydrology by W.F. Hon, 2006, China Ocean Press, and the NOAA World Ocean Atlas, 2009 (http://www.nodc.noaa.gov/OC5/SELECT/ woaselect/woaselect.html).

the bottom water during water stratified season would lead to extremely low $\mathrm{pH}$ and high $p \mathrm{CO}_{2}$ values in bottom waters as a combined result of enhanced organic matter decomposition, $\mathrm{CO}_{2}$ uptake from the atmosphere, and decreased buffer capacity in high $\mathrm{CO}_{2}$ seawaters (Cai et al. 2011).

\section{2. $\mathrm{CO}_{2}$ in the Changjiang River plume}

The Changjiang River is the third longest river in the world after the Amazon and Nile Rivers, and it is the fourth largest in terms of discharge after the Amazon, Congo and Orinoco Rivers. The discharge is the highest in July and the lowest in January. The total annual discharge amounts to $950 \times \mathrm{km}^{3} \mathrm{yr}^{-1}$ with $71 \%$ occurring between May and October (Chen et al. 2008). Naturally, the plume is the most extensive in the summer (Fig. 7.3C) and peaks in August, one month after the peak flow. 
In August, the plume extends to the northeast because of the southwest monsoon. An S $=32$ isoline reaches the Korea Strait and part of the so called Changjiang Diluted Water (CDW), a popular name for the "river plume" in the region, enters the Sea of Japan (Senjyu et al. 2006).

By the fall, the plume occupies a much smaller area owing to a lower discharge (Fig. 7.3D). Because of the northeast monsoon, the CDW extends toward the southwest along the coast of China, with the $\mathrm{S}=30$ isoline reaching the mid-Taiwan Strait and an $\mathrm{S}=32$ isoline extending well into the South China Sea as the alongshore current, although several smaller rivers along the coast also contribute to the low salinity coastal current. In February, the plume occupies the smallest area (Fig. 7.3A), before starting to grow again in spring. In May, a bulge of the CDW starts to extend toward to the northeast (Fig. 7.3B).

Time and again, the East China Sea (ECS) has been found to be a sink of $\mathrm{CO}_{2}$ (Chen and Wang 1999; Tsunogai et al. 1999; Chou et al. 2009a; Zhai and Dai 2009; Tseng et al. 2011). This is in part because the Changjiang River not only exports a significant amount of nutrients to the ECS but also a large quantity of freshwater, which also helps to induce an estuarine type flow. That is, the lighter, fresher water flows out of the shelf on the surface, whereas the subsurface, nutrient-rich waters upwell onto the shelf (Chen and Wang 1999; Chen et al. 2008). The high biological production associated with nutrients brought by the river and this upwelling reduces the $p \mathrm{CO}_{2}$ in surface waters to below $200 \mu \mathrm{atm}$ in the area affected by the Changjiang River plume most of the year.

To date, Zhai and Dai (2009) have provided the most comprehensive seasonal sea-to-air $\mathrm{CO}_{2}$ flux data in the ECS; i.e., 8.8, 4.9, -2.9 , and $10.4 \mathrm{mmol} \mathrm{m}^{-2} \mathrm{~d}^{-1}$, in spring, summer, autumn, and winter, respectively. The area of the plume $(S<30)$ has also been estimated by Kang et al. (2013) as $73 \times 10^{3}, 88 \times 10^{3}, 127 \times 10^{3}$, and $96 \times 10^{3} \mathrm{~km}^{2}$, in February, May, August, and November, respectively. Multiplying these fluxes by the corresponding areas results in a total annual absorption of $2 \mathrm{Tg} \mathrm{C} \mathrm{yr}^{-1}$ for the Changjiang River Plume.

\section{3. $\mathrm{CO}_{2}$ in the Mississippi River plume}

The Mississippi-Atchafalaya river system is the largest river in North America, with an annual load of $580 \mathrm{~km}^{3}$ of freshwater exported to the northern Gulf of Mexico (Milliman and Meade 1983). The Mississippi River splits into two rivers before empting into the Gulf of Mexico, with the Atchafalaya River receiving a combined total of approximately $30 \%$ water of the Mississippi and a local river, which has lower $\mathrm{HCO}_{3}{ }^{-}$content than the Mississippi. A large part of the freshwater discharge forms a stratified coastal current known as the Louisiana Coastal Current (Wiseman et al. 1997). The size and shape of the plume is strongly affected by wind and current patterns. Persistent southeast winds over the region set up a western flow over the shelf through most of the year except in summer (Ohlmann and Niiler 2005; Hetland and Dimarco 2008). Large-scale circulation patterns often retain the freshwater on the shelf, although the river flow is reduced in summer (Rabalais et al. 1996).

$p \mathrm{CO}_{2}$ is very high in the lower Mississippi River (Dagg et al. 2005; Cai and Lohrenz 2010). It ranged from about $1,000 \mu \mathrm{atm}$ in January to 2,200 $\mu \mathrm{atm}$ in July at the Mississippi river mouth and in the Atchafalaya Bay and other coastal bays (based on unpublished data from more than 10 cruises conducted by the Cai laboratory). Once outside the river channels, salinity increases and $p \mathrm{CO}_{2}$ decreases rapidly, except in the case of extreme flooding conditions near the Atchafalaya Bay 


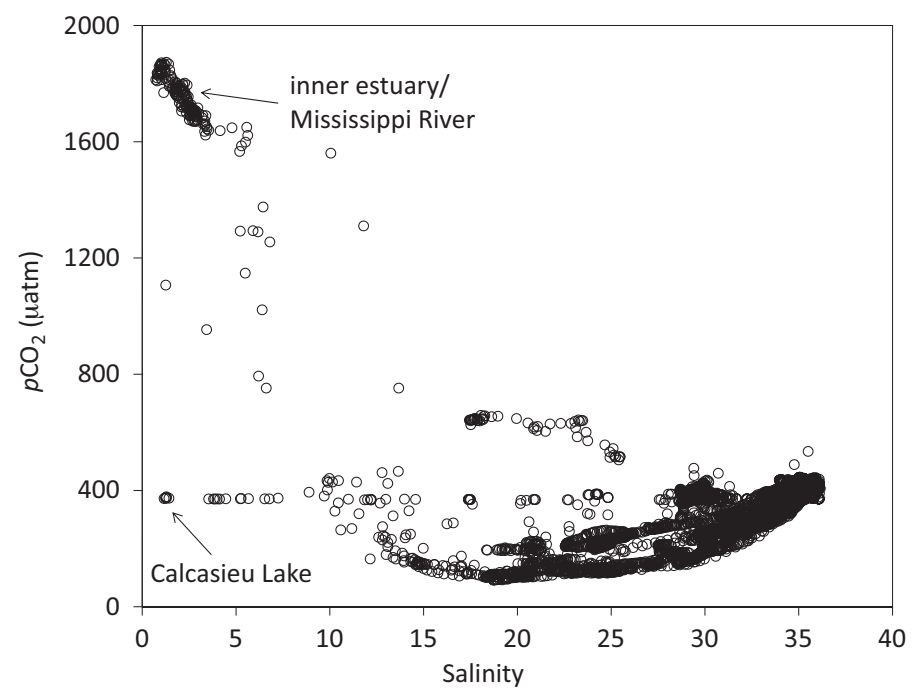

Figure 7.4. $p \mathrm{CO}_{2}$ vs. salinity plot in the Northern Gulf of Mexico from a June 2006 field survey (unpublished data from Cai laboratory). Very high $p \mathrm{CO}_{2}$ (over 1,200 $\mu \mathrm{atm}$ ) was measured in the main channel of the Mississippi River at the Southwest Pass in eastern Louisiana. Calcasieu Lake, located in south Louisiana, is an isolated coastal bay connected to the shelf water through a coastal water way.

(Bianchi et al., 2013). $p \mathrm{CO}_{2}$ can be reduced to below $100 \mu$ atm with an increase in $\mathrm{pH}$ to above 8.5; these values are close to theoretical predictions for a complete biological use of riverine $\mathrm{NO}_{3}{ }^{-}$ (Fig. 7.2). As expected, intensive biological $\mathrm{CO}_{2}$ fixation into biomass, owing to very high nutrient concentrations in the river, could reduce $p \mathrm{CO}_{2}$ to very low values. Air-sea $\mathrm{CO}_{2}$ flux in the inner shelf during late spring was found to be as high as -10 to $-15 \mathrm{mmol} \mathrm{m}^{-2} \mathrm{~d}^{-1}$. Beyond the mid-field regions of the plume, $p \mathrm{CO}_{2}$ increases with salinity increase (or distance from shore) and gradually approaches (in spring and winter) or exceeds atmospheric levels (during the summer and fall) in offshore areas (Fig. 7.4). Hence there is not a simple correlation between $p \mathrm{CO}_{2}$ and salinity in these highly dynamic large river plumes. This is also probably true for other middle-latitude coastal shelves impacted by larger rivers (e.g., see Zhai and Dai 2009 for the Changjiang and Guo et al. 2009 for the Pearl). This feature is in great contrast to that observed in tropical large river plumes (see next section).

Regionally and seasonally averaged based on data from more than 10 cruises in the northern Gulf of Mexico, the inner shelf ( $<20 \mathrm{~m}$ but excluding bays and estuaries) is a sink of atmospheric $\mathrm{CO}_{2}$ $\left(-3.35 \mathrm{mmol} \mathrm{m}^{-2} \mathrm{~d}^{-1}\right)$, the middle shelf is usually neutral $\left(-0.08 \mathrm{mmol} \mathrm{m}^{-2} \mathrm{day}^{-1}\right)$, and the outer shelf is a weak source of $\mathrm{CO}_{2}\left(1.46 \mathrm{mmol} \mathrm{m}{ }^{-2} / \mathrm{d}^{-1}\right)$. The Louisiana shelf is a $\mathrm{CO}_{2}$ sink for the atmosphere, with an annual mean air-sea $\mathrm{CO}_{2}$ flux value of $-0.96 \mathrm{~mol} \mathrm{C} \mathrm{m}^{-2} \mathrm{yr}^{-1}$. Total flux in the northern Gulf of Mexico (within a survey area of 39,523 $\mathrm{km}^{2}$ ) is $-0.46 \mathrm{TgC} / \mathrm{yr}$ (Cai laboratory, unpublished results; Huang 2013).

Regarding carbonate system distribution and dynamics, the northern Gulf of Mexico shelf appears as a three end-member mixing system except during the extremely low discharge time (later summer) when the Atchafalaya River has essentially Mississippi River water (Cai 2003; Guo et al. 2012; Huang et al. 2012). In addition, river end-member values can change with time rapidly. Thus TAlk 

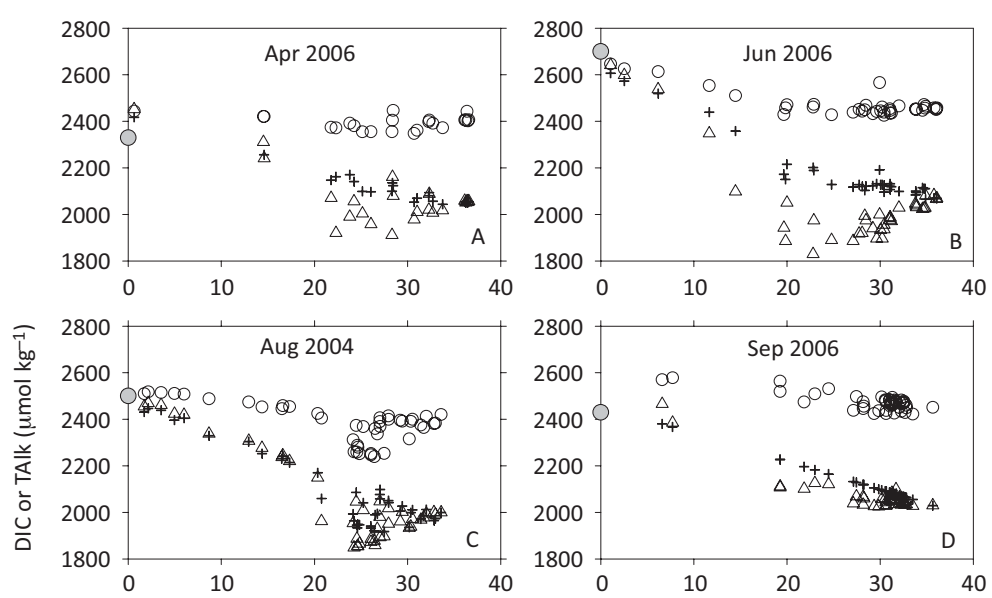

Legend of panels A-E

o observed TAlk

$\triangle$ observed DIC

+ conservative DIC

- TAlk in Mississippi
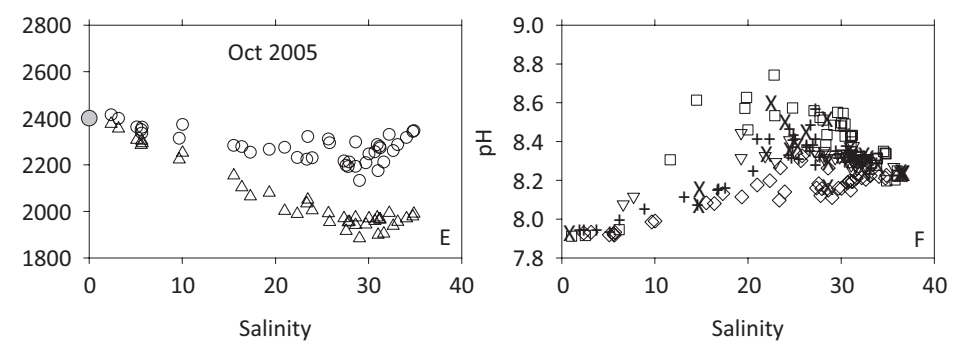

Legend of panel $\mathrm{F}$

$X \quad \mathrm{pH}$ in Apr 2006

口 $\mathrm{pH}$ in Jun 2006

$+\quad$ pH in Aug 2004

$\nabla \quad$ pH in Sep 2006

$\diamond \mathrm{pH}$ in Oct 2005

Figure 7.5. DIC and TAlk vs. salinity plots from several cruises in the northern Gulf of Mexico. + indicates predicted DIC values from a conservative mixing model (from salinity and TAlk). The difference between the predicted DIC and observed (and lower) DIC indicates biological uptake. Such mixing values are not given for October 2005, as the properties were completely dominated by mixing after hurricanes Katrina and Rita. Modified after Guo et al. (2012).

does not show simple conservative behavior when examined against salinity in most time of the year (Fig. 7.5). The deviation of TAlk from the linear mixing of the Mississippi River and the ocean would reflect the influences of the third end-member and end-member variations and thus still can be used to separate the biological DIC removal from physical mixing. Thus the difference between the predicted DIC (from salinity and TAlk) and observed (and lower) DIC indicates biological uptake (Fig. 7.5). By dividing the biological uptake by a plume travel time, one can also derive the net community production (NCP) rates. The NCP rates at the maximum DIC removal area (so called mid-salinity zone or mid-field) can be as high as more than $0.3 \mathrm{~mol} \mathrm{C} \mathrm{m}^{-2} \mathrm{~d}^{-1}$ (or more than $3 \mathrm{gC} \mathrm{m}^{-2} \mathrm{~d}^{-1}$ ), highest among all larger river plumes (Cai 2003; Guo et al. 2012). In contrast, DIC removal in the Amazon River plume is much smaller (is nearly invisible in the DIC to salinity plot, see Fig. 7.6 in the next section). We interpret this stark contrast as evidence of a strong anthropogenic nutrient influence on the biological production of coastal ocean waters in areas near population centers. Other factors also matter. For example, the Mississippi River has lower turbidity than the Changjiang River, and thus high biological production and $\mathrm{CO}_{2}$ removal in the plume has occurred at low salinity zone of 20 to 30 or occasionally even at salinity as low as 12 (Dagg et al. 2008; Huang et al. 2012) in the Mississippi plume, whereas in the Changjiang plume, biological bloom rarely has occurred at salinity less than 28 . 

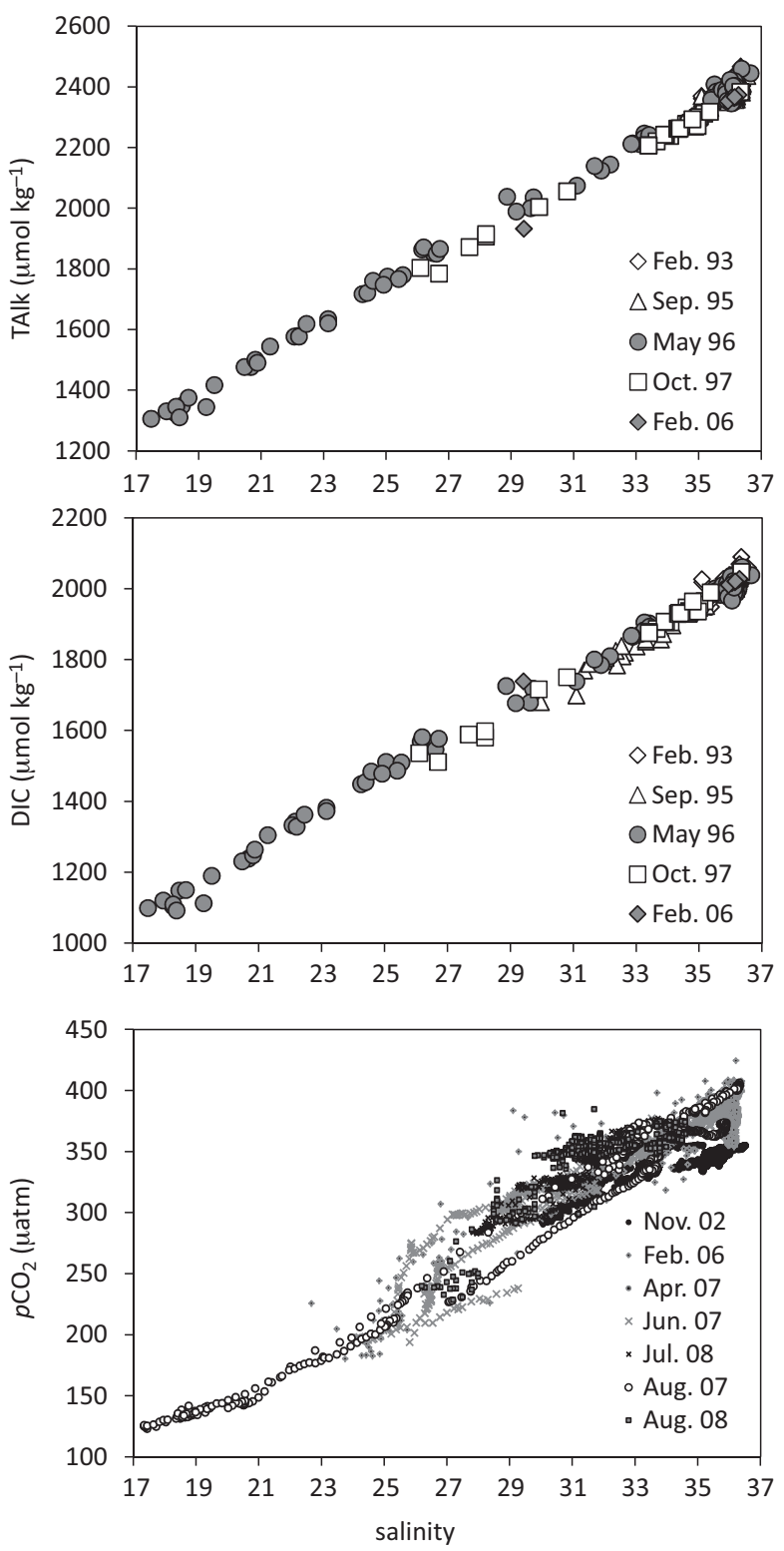

Figure 7.6. TAlk, DIC, and the $p \mathrm{CO}_{2}$ vs. salinity distributions from the Amazon River plume (reproduced based on data supplied by N. Lefèvre). See Lefèvre et al. (2010) for site and method description and for further discussion. 


\section{4. $\mathrm{CO}_{2}$ in the Amazon River plume}

The Amazon is the largest river in the world in terms of freshwater discharge $\left(5,520 \mathrm{~km}^{3} \mathrm{yr}^{-1}\right)$ and watershed size $\left(6.910^{6} \mathrm{~km}^{2}\right)$, and accounts for $\sim 30 \%$ of fresh water discharge to the Atlantic Ocean (Wisser et al. 2010). Discharge ranges from 2,500 $\mathrm{km}^{3} \mathrm{yr}^{-1}$ (November) to 7,600 $\mathrm{km}^{3}$ $\mathrm{yr}^{-1}$ (late May) (Lentz 1995). The Amazon River mouth is located at the equator, and the plume propagates northwestward toward the Caribbean with the North Brazilian Current, Guyana Current, and Caribbean Current. Part of the Amazon plume propagates eastward (at $3^{\circ}-10^{\circ} \mathrm{N}$ ) carried by the North Equatorial Counter Current (Müller-Karger et al. 1989). Over the Brazilian shelf, the plume water is on the top 3 to $10 \mathrm{~m}$, and offshore the plume waters reach depths of 40-45 m (Lentz and Limeburner 1995; Hellweger and Gordon 2002). The Amazon River plume can be detected in satellite ocean color data over areas as large as 500,000 km² (Muller-Karger et al. 1988; Salisbury et al. 2011).

$\mathrm{CO}_{2}$ data in the Amazon River plume have been reported by Ternon et al. (2000), Körtzinger (2003), Cooley et al. (2007), and Lefèvre et al. (2010). DIC and TAlk showed quasi-conservative mixing behavior while $p \mathrm{CO}_{2}$ is below atmospheric equilibrium, in contrast with surrounding waters of the tropical Atlantic Ocean that are above atmospheric equilibrium (Fig. 7.6). The relationship between $p \mathrm{CO}_{2}$ and sea surface salinity (SSS) is remarkably similar among the different studies, with the lowest $p \mathrm{CO}_{2}$ value of $125 \mu \mathrm{atm}$ reported at an SSS value of 18 by Lefèvre et al. (2010). Here, $p \mathrm{CO}_{2}$ is nearly linearly related to SSS, in great contrast to the complex relationships observed in subtropical and middle-latitude coastal oceans impacted by nutrient-rich large rivers such as in the case of the Mississippi (Fig. 7.4), Changjiang (Zhai and Dai 2009), and the Pearl (Guo et al. 2009). Seasonal variations of $p \mathrm{CO}_{2}$ were also found to be low in the Amazon River plume (Fig. 7.6), in great contrast with those found in river plumes at subtropical and temperate latitudes, where seasonal oscillations from $\mathrm{CO}_{2}$ over-saturation (typically in winter or fall) to under-saturation (typically in spring or summer) are observed (Borges and Frankignoulle 2002; Lohrenz and Cai 2006; Chou et al. 2009a; Chou et al. 2009b; Guo et al. 2009; Zhai and Dai 2009; Vandemark et al. 2011; Bozec et al. 2012). Another great contrast between the Amazon plume and some of the other large river plumes is in the DIC (or TAlk) to salinity relationship, which does not show a substantial removal in the Amazon plume (Fig. 7.6), whereas such overall removal is apparent in the Mississippi plume (Fig. 7.5) (Cai 2003; Guo et al. 2012; Huang et al. 2012), in the Pearl River plume (Cai et al. 2004; Dai et al. 2008), and the Changjiang plume (Wang et al. 2000; Chou et al. 2009b).

The low $p \mathrm{CO}_{2}$ values in the Amazon River plume are due to a combination of thermodynamic effect of mixing of river water with seawater (Fig. 7.2) and biological drawdown within the plume owing to increasing light availability as suspended particles sediment in the delta. Cooley et al. (2007) highlighted the role of diazotroph-supported NCP in sustaining the biological drawdown of $\mathrm{CO}_{2}$ within the Amazon plume. However, the nearly linear DIC-to-salinity relationship indicates that net biological production rate, at least in a per-volume base, is much lower in the Amazon plume than in the Mississippi and Changjiang plumes. For example, NCP rates estimated from within plume DIC removal were 0.9-1.6 $\mathrm{gC} \mathrm{m}^{-2} \mathrm{~d}^{-1}$ for the Amazon (Ternon et al. 2000) and 1-8 $\mathrm{gC} \mathrm{m}^{-2} \mathrm{~d}^{-1}$ for the Mississippi plume (Lohrenz et al. 1997; Lohrenz et al. 1999; Guo et al. 2012), whereas the mixed layer depth of the former is nearly 10 times that of the latter. This conclusion is consistent with a comparison of measured biological production rates (see Table 4 of Guo et al. 2012). Finally, 
we have to point out that all of the mixing models in the Amazon River plume between river and marine end-members ignore processes occurring in the extensive inner estuary $\left(44,200 \mathrm{~km}^{2}\right.$, Borges 2005 ) with extensive flooded areas where $p \mathrm{CO}_{2}$ is extremely dynamic and strongly deviate from conservative mixing (Gwenaël Abril, unpublished manuscript).

Körtzinger (2003) used a $p \mathrm{CO}_{2}$ versus SSS relationship (SSS >30) and the monthly climatological SSS means of the Word Ocean Atlas 2001 to integrate air-sea $\mathrm{CO}_{2}$ fluxes. This approach resulted in an overall $\mathrm{CO}_{2}$ sink of $-0.014 \mathrm{Pg} \mathrm{C} \mathrm{yr}^{-1}$ for the plume area of $2.4 \times 10^{6} \mathrm{~km}^{2}$ (defined as $\mathrm{S}<34.9$ ) corresponding to an average air-sea $\mathrm{CO}_{2}$ flux of $-0.5 \mathrm{~mol} \mathrm{~m}^{-2} \mathrm{yr}^{-1}$. Using a similar approach but with a more extensive (SSS $>17$ ) and seasonally resolved dataset, and using instead the monthly fields of SSS from the World Ocean Atlas 2005, Lefèvre et al. (2010) estimated a $\mathrm{CO}_{2}$ flux of -0.35 mol m${ }^{-2} \mathrm{yr}^{-1}$ and a lower Amazon River plume surface area of $1.1 \times 10^{6} \mathrm{~km}^{2}$ (also defined as $\mathrm{S}<$ 34.9). Thus Lefèvre et al. (2010) gave an integrated $\mathrm{CO}_{2}$ flux of $-0.005 \mathrm{Pg} \mathrm{C} \mathrm{yr}^{-1}$ for the Amazon River plume. These fluxes are extremely low compared with the $\mathrm{CO}_{2}$ emission from the Amazon River itself ( $0.5 \mathrm{Pg} \mathrm{C} \mathrm{yr}^{-1}$, Richey et al. 2002). It should also be noted here that there is no published estimate available for the Amazon River inner estuary.

\section{A tentative estimate of global river-plume $\mathrm{CO}_{2}$ flux}

Deriving a global $\mathrm{CO}_{2}$ flux estimate requires a sufficient number of $\mathrm{CO}_{2}$ flux measurements adequately accounting for seasonal and spatial variability within a given system and also surface area estimates for scaling the data. In addition, consistent data from multiple systems are preferred for a reliable global extrapolation. The number of projects acquiring $\mathrm{CO}_{2}$ data in large river plumes has increased steadily over the last decade. Also, high-quality coastal $\mathrm{CO}_{2}$ data are being banked in the international and public databases such as Carbon Dioxide Information Analysis Center and are being included in large data compilations such as Surface Ocean $\mathrm{CO}_{2}$ Atlas (SOCAT, Pfeil et al. 2012). Hence, in the near future, it should be possible to estimate the global air-sea $\mathrm{CO}_{2}$ flux in river plumes with high confidence with the approach outlined previously as the number of studies acquiring $\mathrm{CO}_{2}$ data in large river plumes increase and become available.

To the best of our knowledge, there is no published global estimate of river plume surface areas. The most straightforward way to achieve this would be to use SSS as a tracer of river plumes. This can be estimated on a global basis using remote sensing products. Direct determination of SSS from AQUARIUS or Soil Moisture and Ocean Salinity satellite missions is probably inadequate because the resolution of the products is $\sim 50 \mathrm{~km}$. Another possibility would be to derive SSS in river plumes from remote sensed colored dissolved organic carbon (CDOM) as applied in several studies in the Amazon (Salisbury et al. 2011), Changjiang (Bai et al. 2013), Mississippi (Lohrenz et al. 2010; Zhu et al. 2011), and Columbia (Palacios et al. 2009). However, algorithms for the retrieval of SSS from remote sensed CDOM are needed on a regional basis (site-specific) in scope, because CDOM values at river end-members are highly variable (Blough and Del Vecchio 2002). Also, CDOM-SSS relationships can seasonally depart from linearity for a variety of CDOM production or removal processes (additional end-members, phytoplankton CDOM release, bacterial utilization or photooxidation). Therefore, we take a first-order approximation in this chapter in hope of making some progress regarding this issue. 
Table 7.2. Air-Water $\mathrm{CO}_{2}$ flux (mol $\left.\mathrm{m}^{-2} \mathrm{yr}^{-1}\right)$, surface area $\left(\mathrm{km}^{2}\right)$, and freshwater discharge for major river plumes

\begin{tabular}{lccccl}
\hline \hline & $\begin{array}{c}\text { Freshwater } \\
\text { discharge } \\
\left(\mathrm{km}^{3} \mathrm{yr}^{-1}\right)\end{array}$ & $\begin{array}{c}\text { Plume surface } \\
\left(\mathrm{km}^{2}\right)\end{array}$ & $\begin{array}{c}\text { Area to } \\
\text { discharge } \\
\text { ratio }\end{array}$ & $\begin{array}{c}\text { Air-water } \\
\mathrm{CO}_{2} \text { flux } \\
\left(\mathrm{mol} \mathrm{m}^{-2} \mathrm{yr}^{-1}\right)\end{array}$ & Reference \\
\hline Amazon & 5520 & $2,400,000^{(1)}$ & 438 & -0.50 & Körtzinger (2003) \\
Changjiang & 950 & $1,100,000^{(1)}$ & 199 & -0.35 & Lefèvre et al. (2010) \\
Mississippi & 580 & $85,000^{(2)}$ & 90 & -1.90 & Zhai \& Dai (2009) \\
Loire & 18 & $22,000^{(3)}$ & 38 & -0.96 & Cai unpublished \\
Bozec et al. (2012)
\end{tabular}

Note: ${ }^{(1)}$ Both Körtzinger (2003) and Lefèvre et al. (2010) defined the Amazon River plume for $\mathrm{S}<34.9$ in the area $3^{\circ} \mathrm{S}-18^{\circ} \mathrm{N}, 30-60^{\circ} \mathrm{W}$, but the former used the data from the World Ocean Atlas 2001 and the latter used the World Ocean Atlas 2005. ${ }^{(2)}$ Changjiang River plume area comes from Tseng et al. (2011) based on data in their Fig. 2 and Kang et al. (2013), defined as S < 30. ${ }^{(3)}$ The Mississippi River plume is from Kang et al. (2013) defined as S $<31$ and from W.-J. Cai unpublished. Earlier Green et al. (2006) had provided a very small plume area of 2,200 $\mathrm{km}^{2}$ immediately outside the Southwest Pass of the Mississippi, which was defined as the area with a suspended particle concentration over $5 \mathrm{mg} \mathrm{L}^{-1}$. If a one-month water residence time is assumed, a plume of $22,000 \mathrm{~km}^{2} \mathrm{or}$ $2,200 \mathrm{~km}^{2}$ would indicate a mixed layer depth of 2.2 or $22 \mathrm{~m}$, respectively, using the Mississippi River discharge rate, suggesting that the high end plume area is reasonable. However, these two plume area estimates are not necessarily at odds, as the latter is defined as the turbidity plume, whereas the former is defined based on salinity and is thus more consistent with other definition in this chapter. ${ }^{(4)}$ Loire plume area was defined for S $<34.4$ by Bozec et al. (2012).

Table 7.2 summarizes existing knowledge on air-sea $\mathrm{CO}_{2}$ fluxes in major river plumes and additional physical data (surface area and freshwater discharge). It appears that all known large river plumes are net sinks for atmospheric $\mathrm{CO}_{2} . p \mathrm{CO}_{2}$ values below atmospheric equilibrium also have been reported in other major river plumes, such as the Niger River (Körtzinger 2009) and the Congo River (Bakker et al. 1999; Lefèvre 2009); however, integrated air-water $\mathrm{CO}_{2}$ fluxes have not been computed as data coverage is quite low in these systems. It should also be noted that very small river plumes such as the Scheldt estuary (freshwater discharge $<4 \mathrm{~km}^{3} \mathrm{yr}^{-1}$ ) and the Kennebec (freshwater discharge $\left.\sim 8 \mathrm{~km}^{3} \mathrm{yr}^{-1}\right)$ are a net source of $\mathrm{CO}_{2}$ to the atmosphere $\left(+1.9 \mathrm{~mol} \mathrm{~m}^{-} \mathrm{yr}^{-1}\right.$ (Borges and Frankignoulle 2002) and $+0.9 \mathrm{~mol} \mathrm{~m}^{-} \mathrm{yr}^{-1}$ (Salisbury et al. 2009).

Although there is a general increasing pattern of river plume surface area with discharge (Table 7.2), we are not able to derive a simple relationship from these few data-points. This could be due to a variety of reasons such as inconsistency in the definitions and methods to derive river plume areas (e.g., see notes below Table 7.2) as well as interactions with topography and/or dispersal by wind. Nevertheless, we attempted a crude global extrapolation of $\mathrm{CO}_{2}$ fluxes for river plumes based on the limited dataset shown in Table 7.2. The intuitive notion is that there should be a general positive relationship between river plume surface area and freshwater discharge.

For our estimate, we removed the Amazon discharge $\left(5,520 \mathrm{~km}^{3} \mathrm{yr}^{-1}\right)$ from the global freshwater discharge of $37,288 \mathrm{~km}^{3} \mathrm{yr}^{-1}$ (Dai and Trenberth 2002). To this value $\left(31,768 \mathrm{~km}^{3} \mathrm{yr}^{-1}\right.$ ) we applied a ratio of river plume surface area $\left(\mathrm{km}^{2}\right)$ to freshwater discharge $\left(\mathrm{km}^{3} \mathrm{yr}^{-1}\right)$ of 38 (for Mississippi) and 90 (for Changjiang), allowing for computation of a range of surface area for all river plumes, excluding the extremely large Amazon River and the very small Loire River. To this value we added 
the two Amazon plume area estimates, allowing us to derive a range of surface area of river plumes globally, ranging between $2.31 \times 10^{6} \mathrm{~km}^{2}$ and $5.26 \times 10^{6} \mathrm{~km}^{2}$ (i.e., 9-20\% of global continental shelf area; Walsh 1988). If we scale the surface area weighted mean of air-water $\mathrm{CO}_{2}$ fluxes given in Table $7.2\left(-0.49 \mathrm{~mol} \mathrm{~m}^{-} \mathrm{yr}^{-1}\right)$, this would give a global $\mathrm{CO}_{2}$ sink ranging between -0.014 and -0.031 $\mathrm{PgC} \mathrm{yr}{ }^{-1}$. Alternatively, if we scale the arithmetic mean of air-water $\mathrm{CO}_{2}$ fluxes given in Table 7.2 $\left(-1.04 \mathrm{~mol} \mathrm{~m}^{-} \mathrm{yr}^{-1}\right)$, this would provide a global $\mathrm{CO}_{2}$ sink ranging between -0.029 and $-0.066 \mathrm{PgC}$ $\mathrm{yr}^{-1}$. Note that a recent work estimated the annual mean area of global river plumes to be $3.72 \times 10^{6}$ $\mathrm{km}^{2}$, which is approximately $14 \%$ of the total continental shelves area worldwide (Kang et al. 2013). As this work only counted plume areas that were three salinity units lower than the associated ocean

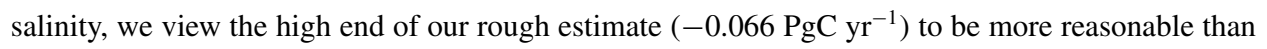
the lower end estimate.

The tentative global sink of $\mathrm{CO}_{2}$ in river plumes ranging between -0.014 and $-0.066 \mathrm{PgC} \mathrm{yr}^{-1}$ is to a large extent driven by the sink in the Amazon River plume $\left(-0.005\right.$ to $\left.-0.014 \mathrm{PgC} \mathrm{yr}^{-1}\right)$. We notice that this flux only represents $12-26 \%$ of the currently best estimated global continental shelf $\mathrm{CO}_{2}$ sink of $\sim-0.25 \mathrm{PgC} \mathrm{yr}^{-1}$ (Cai et al. 2006; Laruelle et al. 2010) and does not balance the $\mathrm{CO}_{2}$ source from inner estuaries $\left(\sim+0.25 \mathrm{PgC} \mathrm{yr}^{-1}\right)$ (Table 7.1). The global river plume $\mathrm{CO}_{2}$ sink is much smaller compared with the $\mathrm{CO}_{2}$ sink in the open ocean ranging between $-1.4 \mathrm{PgC} \mathrm{yr}^{-1}$ and $-2.2 \mathrm{PgC} \mathrm{yr}^{-1}$ (Gruber et al. 2009; Takahashi et al. 2009). We acknowledge that this global plume $\mathrm{CO}_{2}$ sink estimate is very crude. Yet available data converge to the fact that large river plumes are sinks of atmospheric $\mathrm{CO}_{2}$ (Table 7.2). We suggest that currently the largest unknown term is in the global surface area of large river plumes, which we propose as between $2.31 \times 10^{6} \mathrm{~km}^{2}$ and $5.26 \times 10^{6}$ $\mathrm{km}^{2}$. However, we do not believe that the true plume can be an order of magnitude higher (23 to $\left.52 \times 10^{6} \mathrm{~km}^{2}\right)$ or as large as $6-15 \%$ of the global ocean area $\left(362 \times 10^{6} \mathrm{~km}^{2}\right)$. Only in that scenario, the plume flux can be significant in a global scale, which we view as highly unlikely. However, such plume-induced $\mathrm{CO}_{2}$ flux can be highly significant in regional air-sea $\mathrm{CO}_{2}$ budget and represents important biogeochemical processes.

In summary, large river plumes are highly dynamic in terms of $\mathrm{CO}_{2}$ distributions. They are frequently under-saturated in $\mathrm{CO}_{2}$ with respect to atmospheric equilibrium owing to biological activity and thermodynamic effect on the marine carbonate system of mixing of river and seawater. The latter effect is more marked in poorly buffered low-latitude rivers owing to lower $\mathrm{HCO}_{3}{ }^{-}$concentrations in river water. Tropical river plumes such as the Amazon seem to show more or less seasonally stable $p \mathrm{CO}_{2}$-SSS relationships, whereas in subtropical and temperate (e.g., Mississippi, Changjiang and Pearl, and Loire) systems, $p \mathrm{CO}_{2}$ is more variable seasonally, typically above equilibrium in fall/winter and below equilibrium in spring/summer. Consistently, although DIC-SSS and TAlk-SSS indicate quasi-conservative mixing behavior in the Amazon River, they show a nonconservative behavior in subtropical-temperate systems such as the Mississippi and Changjiang River, where biological $\mathrm{CO}_{2}$ fixation draws down DIC greatly beyond the prediction from the conservative mixing behavior. Available air-sea $\mathrm{CO}_{2}$ flux estimates indicate that the Amazon, Changjiang, Mississippi, and Loire river plumes are net sinks of atmospheric $\mathrm{CO}_{2}$ ranging from -0.4 to $-1.9 \mathrm{~mol} \mathrm{~m}^{-} \mathrm{yr}^{-1}$. Based on a crude estimate of the global extent of river plumes, we have integrated the $\mathrm{CO}_{2}$ sink. Current best estimate suggests that large river plumes contribute at most to $\sim 25 \%$ of the continental shelf $\mathrm{CO}_{2}$ sink and to $\sim 3 \%$ of the global oceanic $\mathrm{CO}_{2}$ sink. 


\section{Acknowledgment}

We thank Kang et al. of the Second Institution of Oceanography, Hangzhou, China, for providing an advanced copy of their paper and helping with the Changiiang plume extension information (Figure 7.3). W.-J. Huang and X. Guo helped with plotting Figures 7.4 and 7.5. W.-J. Huang also provided $\mathrm{CO}_{2}$ flux estimate in the Mississippi River plume. We thank Tom Bianchi for improving the text. A.V.B. is a research associate at the FRS-FNRS. W.-J.C. acknowledges the support of the National Science Foundation (OCE-0752110) and NASA (NNX10AU06G, NNX12AB21G, and NNX12AP84G).

\section{References}

Abril, G., and A.V. Borges. 2004. Carbon dioxide and methane emissions from estuaries, In: Tremblay, A., Varfalvy, L., Roehm, C., and Garneau, M. (eds.), Greenhouse Gases Emissions from Natural Environments and Hydroelectric Reservoirs: Fluxes and Processes. Berlin: Springer-Verlag, pp. 187-207.

Bai, Y., D. Pan, W.-J. Cai, X. He, D. Wang, B. Tao, and Q. Zhu. 2013. Remote sensing of salinity from satellite-derived CDOM in the Changjiang River dominated East China Sea. J. Geophys. Res.: Oceans 118: 227-243.

Bakker, D. C. E., H. J. W. de Baar, and E. de Jong. 1999. The dependence on temperature and salinity of dissolved inorganic carbon in East Atlantic surface waters. Mar. Chem. 65(3-4): 263-280.

Bianchi, T.S., and M.A. Allison. 2009. Large-river delta-front estuaries as natural "recorders" of global environmental change. Proc. Natl. Acad. Sci. 106: 8085-8092.

Bianchi, T.S., Garcia-Tigreros, F., Yvon-Lewis, S.A., Shields, M., Mills, H.J., Butman, D., Osburn, C., Raymond, P., Shank, G.C., DiMarco, S.F., Walker, N., Reese, B.K., Mullins-Perry, R., Quigg, A., Aiken, G.R., Grossman, E.L.. 2013. Enhanced transfer of terrestrially derived carbon to the atmosphere in a flooding event. Geophys. Res. Lett. 40: 116-122.

Blough, N.V., and R. Del Vecchio. 2002. Chromophoric DOM in the coastal environment, In: Hansell, D.A., and Carlson, C.A. (eds.), Biogeochemistry of Marine Dissolved Organic Matter. Amsterdam: Academic Press, pp. 509-546.

Borges, A.V. 2005. Do we have enough pieces of the jigsaw to integrate $\mathrm{CO}_{2}$ fluxes in the Coastal Ocean? Estuaries 28: 3-27.

Borges, A.V., and G. Abril. 2011. 5.04 - Carbon Dioxide and Methane Dynamics in Estuaries, In: Eric, W., and Donald, M. (eds.), Treatise on Estuarine and Coastal Science. Amsterdam: Academic Press, pp. 119-161.

Borges, A.V., B. Dellile, and M. Frankignoulle. 2005. Budgeting sinks and sources of $\mathrm{CO}_{2}$ in the coastal oceans: Diversity of ecosystems counts. Geophys. Res. Lett. 32: L14601.

Borges, A.V., and M. Frankignoulle. 2002. Distribution and air-water exchange of carbon dioxide in the Scheldt plume off the Belgian coast. Biogeochemistry 59: 41-67.

Borges, A.V., and N. Gypens. 2010. Carbonate chemistry in the coastal zone responds more strongly to eutrophication than ocean acidification. Limnol. Oceanogr. 55: 346-353.

Bouillon, S., A. Yambélé, R.G.M. Spencer, D.P. Gillikin, P.J. Hernes, J. Six, R. Merckx, and A.V. Borges. 2012. Organic matter sources, fluxes and greenhouse gas exchange in the Oubangui River (Congo River basin). Biogeosciences 9: 2045-2062.

Bozec, Y., T. Cariou, E. Macé, P. Morin, D. Thuillier, and M. Vernet. 2012. Seasonal dynamics of air-sea CO2 fluxes in the inner and outer Loire estuary (NW Europe). Estuar. Coast. Shelf Sci. 100: 58-71.

Cai, W.-J. 2003. Riverine inorganic carbon flux and rate of biological uptake in the Mississippi River plume. Geophys. Res. Lett. 30: 1032. 
Cai, W.-J. 2011. Estuarine and coastal ocean carbon paradox: $\mathrm{CO}_{2}$ sinks or sites of terrestrial carbon incineration? Ann. Rev. Mar. Sci. 3: 123-145.

Cai, W.-J., M. Dai, and Y. Wang. 2006. Air-sea exchange of carbon dioxide in ocean margins: a province-based synthesis. Geophys. Res. Lett. 33: L12603.

Cai, W.-J., X. Guo, C.-T. A. Chen, M. Dai, L. Zhang, W. Zhai, S.E. Lohrenz, K. Yin, P.J. Harrison, and Y. Wang. 2008. A comparative overview of weathering intensity and $\mathrm{HCO}_{3}{ }^{-}$flux in the world's major rivers with emphasis on the Changjiang, Huanghe, Zhujiang (Pearl) and Mississippi Rivers. Cont. Shelf Res. 28: 1538-1549.

Cai, W.-J., X. Hu, W.-J. Huang, L. Jiang, Y. Wang, T. H. Peng, and X. Zhang. 2010. Alkalinity distribution in the western North Atlantic Ocean margins. J. Geophys. Res. Ocean., 115(C8), C08014.

Cai, W.-J., Hu, X., Huang, W.-J., Murrell, M.C., Lehrter, J.C., Lohrenz, S.E., Chou, W.-C., Zhai, W., Hollibaugh, J.T., Wang, Y., Zhao, P., Guo, X., Gundersen, K., Dai, M., and Gong, G.-C., 2011. Acidification of subsurface coastal waters enhanced by eutrophication. Nature Geosci 4: 766-770.

Cai, W.-J., and S.E. Lohrenz. 2010. Marginal seas-The Mississippi River plume and adjacent margin in the Gulf of Mexico, In: Liu, K.K., Atkinson, L., Quinones, R., and Talaue-McManus, L. (eds.), A Global Synthesis. Springer.

Cai, W.J., M.H. Dai, Y.C. Wang, W.D. Zhai, T. Huang, S.T. Chen, F. Zhang, Z.Z. Chen, and Z.H. Wang. 2004. The biogeochemistry of inorganic carbon and nutrients in the Pearl River estuary and the adjacent Northern South China Sea. Cont. Shelf Res. 24: 1301-1319.

Chen, C.-T.A., and A.V. Borges. 2009. Reconciling opposing views on carbon cycling in the coastal ocean: continental shelves as sinks and near-shore ecosystems as sources of atmospheric $\mathrm{CO}_{2}$. Deep Sea Res. Part II Top. Stud. Oceanogr. 56: 578-590.

Chen, C.-T.A., T.-H. Huang, Y.-H. Fu, Y. Bai, and X. He. 2012. Strong sources of $\mathrm{CO}_{2}$ in upper estuaries become sinks of CO2 in large river plumes. Curr. Opin. Environ. Sustain. 4: 179-185.

Chen, C.-T.A., W. Zhai, and M. Dai. 2008. Riverine input and air-sea $\mathrm{CO}_{2}$ exchanges near the Changjiang (Yangtze River) Estuary: status quo and implication on possible future changes in metabolic status. Cont. Shelf Res. 28: 1476-1482.

Chen, C.T.A., and S.L. Wang. 1999. Carbon, alkalinity and nutrient budgets on the East China Sea continental shelf. J. Geophys. Res. Oceans 104: 20675-20686.

Chou, W.-C., G.-C. Gong, D.D. Sheu, C.-C. Hung, and T.-F. Tseng. 2009a. Surface distributions of carbon chemistry parameters in the East China Sea in summer 2007. J. Geophys. Res. 114: C07026.

Chou, W.-C., G.-C. Gong, D.D. Sheu, S. Jan, C.-C. Hung, and C.-C. Chen. 2009b. Reconciling the paradox that the heterotrophic waters of the East China Sea shelf act as a significant CO2 sink during the summertime: evidence and implications. Geophys. Res. Lett. 36: L15607.

Cooley, S.R., V.J. Coles, A. Subramaniam, and P.L. Yager. 2007. Seasonal variations in the Amazon plume-related atmospheric carbon sink. Global Biogeochem. Cycles 21: GB3014.

Dai, A. and K.E. Trenberth 2002. Estimates of freshwater discharge from continents: Latitudinal and seasonal variations. J. Hydrol. 3: 660-687.

Dai, M., Zhai, W., Cai, W.-J., Callahan, J., Huang, B., Shang, S., Huang, T., Li, X., Lu, Z., Chen, W., Chen, Z. 2008. Effects of an estuarine plume-associated bloom on the carbonate system in the lower reaches of the Pearl River estuary and the coastal zone of the northern South China Sea. Cont. Shelf Res. 28: 1416-1423.

Dagg, M.J., T. Bianchi, B. Mckee, and R. Powell. 2008. Fates of dissolved and particulate materials from the Mississippi river immediately after discharge into the northern Gulf of Mexico, USA, during a period of low wind stress. Cont. Shelf Res. 28: 1443-1450. 
Dagg, M.J., T.S. Bianchi, G.A. Breed, W.J. Cai, S. Duan, H. Liu, B.A. McKee, R.T. Powell, and C.M. Stewart. 2005. Biogeochemical characteristics of the lower Mississippi River, USA, during June 2003. Estuaries 28: 664-674.

Dürr, H.H., G.G. Laruelle, C.M. Van Kempen, C.P. Slomp, M. Meybeck, and H. Middelkoop. 2011. Worldwide typology of nearshore coastal systems: Defining the estuarine filter of riverine inputs to the oceans. Estuar. Coasts 34: 441-458.

Frankignoulle, M., G. Abril, A. Borges, I. Bourge, C. Canon, B. DeLille, E. Libert, and J.M. Theate.1998. Carbon dioxide emission from European estuaries. Science 282: 434-436.

Green, R., Bianchi, T., Dagg, M., Walker, N., Breed, G., 2006. An organic carbon budget for the Mississippi River turbidity plume and plume contributions to air-sea $\mathrm{CO}_{2}$ fluxes and bottom water hypoxia. Estuar. Coast. 29: 579-597.

Gruber, N., M. Gloor, S.E. Mikaloff Fletcher, Gruber, N., Gloor, M., Mikaloff Fletcher, S.E., Doney, S.C., Dutkiewicz, S., Follows, M.J., Gerber, M., Jacobson, A.R., Joos, F., Lindsay, K., Menemenlis, D., Mouchet, A., Müller, S.A., Sarmiento, J.L., Takahashi, T., 2009. Oceanic sources, sinks, and transport of atmospheric $\mathrm{CO}_{2}$. Global Biogeochem. Cycles 23: GB1005.

Guo, X., W.-J. Cai, W.-J. Huang. Guo, X., Cai, W.-J., Huang, W.-J., Wang, Y., Chen, F., Murrell, M.C., Lohrenz, S.E., Jiang, L.-Q., Dai, M., Hartmann, J., Lin, Q., Culp, R., 2012. Carbon dynamics and community production in the Mississippi River plume. Limnol. Oceanogr. 57: $1-17$.

Guo, X., M. Dai, W. Zhai, W.-J. Cai, and B. Chen. 2009. $\mathrm{CO}_{2}$ flux and seasonal variability in a large subtropical estuarine system, the Pearl River Estuary, China. J. Geophys. Res. 114: G03013.

Hellweger, F.L., and A.L. Gordon. 2002. Tracing Amazon River water into the Caribbean Sea. J. Mar. Res. 60: 537-549.

Hetland, R.D., and S.F. Dimarco. 2008. How does the character of oxygen demand control the structure of hypoxia on the Texas-Louisiana continental shelf? J. Mar. Syst. 70: 49-62.

Hopkinson, C.S., and E.M. Smith. 2005. Estuarine respiration: an overview of benthic, pelagic, and whole system respiration, In: del Giorgio, P., and Williams, P. (eds.), Respiration in Aquatic Ecosystems. New York: Oxford University Press, pp. 122-147.

Huang, W.-J. 2013. Inorganic carbon distribution and dynamics in the Mississippi River plume on the northern Gulf of Mexico. PhD dissertation, Univ. of Georgia.

Huang, W.J., W.J. Cai, R.T. Powell, S.E. Lohrenz, Y. Wang, L.Q. Jiang, and C.S. Hopkinson. 2012. The stoichiometry of inorganic carbon and nutrient removal in the Mississippi River plume and adjacent continental shelf. Biogeosciences 9: 2781-2792.

Jiang, L.-Q., W.-J. Cai, and Y. Wang. 2008. A comparative study of carbon dioxide degassing in river- and marine-dominated estuaries. Limnol. Oceanogr. 53: 2603-2615.

Kang, Y., D. Pan, Y. Bai, X. He, X. Chen, C.-T. Chen, and D. Wang (2013), Areas of the global major river plumes, Acta Oceanol. Sin. 32(1): 79-88.

Koné, Y.J.M., G. Abril, K.N. Kouadio, B. Delille, and A.V. Borges. 2008. Seasonal Variability of Carbon Dioxide in the Rivers and Lagoons of Ivory Coast (West Africa). Estuar. Coasts 32: 246-260.

Körtzinger, A. 2003. A significant $\mathrm{CO}_{2}$ sink in the tropical Atlantic Ocean associated with the Amazon River plume. Geophys. Res. Lett. 30: 2287.

Körtzinger, A. 2009. The outer Amazon Plume: An atmospheric $\mathrm{CO}_{2}$ sink, In: K.-K. Liu, L. Atkinson, R. Quinones and L. Talaue-McManus (eds.), Carbon and Nutrient Fluxes in Continental Margins, Heidelberg: Springer, pp. 450-453.

Laruelle, G.G., H.H. Dürr, C.P. Slomp, and A.V. Borges. 2010. Evaluation of sinks and sources of $\mathrm{CO}_{2}$ in the global coastal ocean using a spatially-explicit typology of estuaries and continental shelves. Geophys. Res. Lett. 37: L15607. 
Lefèvre, N. 2009. Low $\mathrm{CO}_{2}$ concentrations in the Gulf of Guinea during the upwelling season in 2006. Mar. Chem. 113(1-2): 93-101.

Lefèvre, N., D. Diverrès, and F. Gallois. 2010. Origin of $\mathrm{CO}_{2}$ undersaturation in the western tropical Atlantic. Tellus B 62: 595-607.

Lentz, S.J. 1995. Seasonal variations in the horizontal structure of the Amazon Plume inferred from historical hydrographic data. J. Geophys. Res. 100: 2391-2400.

Lentz, S.J., and R. Limeburner. 1995. The Amazon River Plume during AMASSEDS: Spatial characteristics and salinity variability. J. Geophys. Res. 100: 2355-2375.

Lohrenz, S.E., and W.-J. Cai. 2006. Satellite ocean color assessment of air-sea fluxes of $\mathrm{CO}_{2}$ in a river-dominated coastal margin. Geophys. Res. Lett. 33.

Lohrenz, S.E., W.-J. Cai, F. Chen, X. Chen, and M. Tuel. 2010. Seasonal variability in air-sea fluxes of $\mathrm{CO} 2$ in a river-influenced coastal margin. J. Geophys. Res. 115: C10034.

Lohrenz, S.E., G.L. Fahnenstiel, D.G. Redalje, G.A. Lang, X.G. Chen, and M.J. Dagg. 1997. Variations in primary production of northern Gulf of Mexico continental shelf waters linked to nutrient inputs from the Mississippi River. Mar. Ecol. Prog. Series 155: 45-54.

Lohrenz, S.E., G.L. Fahnenstiel, D.G. Redalje, G.A. Lang, M.J. Dagg, T.E. Whitledge, and Q. Dortch. 1999. Nutrients, irradiance, and mixing as factors regulating primary production in coastal waters impacted by the Mississippi River plume. Cont. Shelf Res. 19: 1113-1141.

Milliman, J.D., and R.H. Meade. 1983. World-wide delivery of sediment to the oceans. J. Geol. 91 : $1-21$.

Müller-Karger, F.E., C.R. Mcclain, T.R. Fisher, W.E. Esaias, and R. Varela. 1989. Pigment distribution in the Caribbean sea: observations from space. Prog. Oceanogr. 23: 23-64.

Muller-Karger, F.E., C.R. Mcclain, and P.L. Richardson. 1988. The dispersal of the Amazon's water. Nature 333: 56-59.

Odum, H.T., and C.M. Hoskin. 1958. Comparative studies of the metabolism of Texas Bays. Publications of the Institute of Marine Science, University of Texas 5: 16-46.

Ohlmann, J.C., and P.P. Niiler. 2005. Circulation over the continental shelf in the northern Gulf of Mexico. Prog. Oceanogr. 64: 45-81.

Palacios, S.L., T.D. Peterson, and R.M. Kudela. 2009. Development of synthetic salinity from remote sensing for the Columbia River plume. J. Geophys. Res. 114: C00B05.

Park, P.K., L.I. Gordon, S.W. Hager, and M.C. Cissel. 1969. Carbon dioxide partial pressure in the Columbia River. Science 166: 867-868.

Pfeil, B., A., Olsen, D.C.E., Bakker, Pfeil, B., Olsen, A., Bakker, D.C.E., Hankin, S., Koyuk, H., Kozyr, A., Malczyk, J., Manke, A., Metzl, N., Sabine, C.L., Akl, J., Alin, S.R., Bellerby, R.G.J., Borges, A., Boutin, J., Brown, P.J., Cai, W.J., Chavez, F.P., Chen, A., Cosca, C., Fassbender, A.J., Feely, R.A., González-Dávila, M., Goyet, C., Hardman-Mountford, N., Heinze, C., Hood, M., Hoppema, M., Hunt, C.W., Hydes, D., Ishii, M., Johannessen, T., Jones, S.D., Key, R.M., Körtzinger, A., Landschützer, P., Lauvset, S.K., Lefèvre, N., Lenton, A., Lourantou, A., Merlivat, L., Midorikawa, T., Mintrop, L., Miyazaki, C., Murata, A., Nakadate, A., Nakano, Y., Nakaoka, S., Nojiri, Y., Omar, A.M., Padin, X.A., Park, G.H., Paterson, K., Perez, F.F., Pierrot, D., Poisson, A., Ríos, A.F., Santana-Casiano, J.M., Salisbury, J., Sarma, V.V.S.S., Schlitzer, R., Schneider, B., Schuster, U., Sieger, R., Skjelvan, I., Steinhoff, T., Suzuki, T., Takahashi, T., Tedesco, K., Telszewski, M., Thomas, H., Tilbrook, B., Tjiputra, J., Vandemark, D., Veness, T., Wanninkhof, R., Watson, A.J., Weiss, R., Wong, C.S., Yoshikawa-Inoue, H., 2012. A uniform, quality controlled Surface Ocean CO2 Atlas (SOCAT). Earth Syst. Sci. Data Discuss. 5: 735-780.

Rabalais, N., R. Turner, D. Justić, Q. Dortch, W. Wiseman, and B. Sen Gupta. 1996. Nutrient changes in the Mississippi River and system responses on the adjacent continental shelf. Estuar. Coasts 19: 386-407. 
Richey, J.E., J.M. Melack, A.K. Aufdenkampe, V.M. Ballester, and L.L. Hess. 2002. Outgassing from Amazonian rivers and wetlands as a large tropical source of atmospheric $\mathrm{CO} 2$. Nature 416: 617-620.

Salisbury, J., M. Green, C. Hunt, and J. Campbell. 2008. Coastal acidification by rivers: a threat to shellfish? Eos 89: 513-514.

Salisbury, J., D. Vandemark, C. Hunt, J. Campbell, B. Jonsson, A. Mahadevan, W. McGillis, and H. Xue. 2009. Episodic riverine influence on surface DIC in the coastal Gulf of Maine. Estuar. Coast. Shelf Sci. 82: 108-118.

Salisbury, J., D. Vandemark, J. Campbell, C. Hunt, D. Wisser, N. Reul, and B. Chapron. 2011. Spatial and temporal coherence between Amazon River discharge, salinity, and light absorption by colored organic carbon in western tropical Atlantic surface waters. J. Geophys. Res. 116: $\mathrm{C} 00 \mathrm{H} 02$.

Senjyu, T., H. Enomoto, T. Matsuno, and S. Matsui. 2006. Interannual salinity variations in the Tsushima Strait and its relation to the Changjiang discharge. J. Oceanogr. 62: 681-692.

Smith, S.V., and J.T. Hollibaugh. 1993. Coastal metabolism and the oceanic organic-carbon balance. Rev. Geophys. 31: 75-89.

Takahashi, T., S.C. Sutherland, R. Wanninkhof, Takahashi, T., Sutherland, S.C., Wanninkhof, R., Sweeney, C., Feely, R.A., Chipman, D.W., Hales, B., Friederich, G., Chavez, F., Sabine, C., Watson, A., Bakker, D.C.E., Schuster, U., Metzl, N., Yoshikawa-Inoue, H., Ishii, M., Midorikawa, T., Nojiri, Y., Körtzinger, A., Steinhoff, T., Hoppema, M., Olafsson, J., Arnarson, T.S., Tilbrook, B., Johannessen, T., Olsen, A., Bellerby, R., Wong, C.S., Delille, B., Bates, N.R., de Baar, H.J.W., 2009. Climatological mean and decadal change in surface ocean $\mathrm{pCO}_{2}$, and net sea-air $\mathrm{CO}_{2}$ flux over the global oceans. Deep Sea Res. Part II Top. Stud. Oceanogr. 56: $554-577$.

Ternon, J.F., C. Oudot, A. Dessier, and D. Diverres. 2000. A seasonal tropical sink for atmospheric CO2 in the Atlantic ocean: the role of the Amazon River discharge. Mar. Chem. 68: 183-201.

Tseng, C.-M., K.K. Liu, G.C. Gong, P.Y. Shen, and W.J. Cai. 2011. CO2 uptake in the East China Sea relying on Changjiang runoff is prone to change. Geophys. Res. Lett. 38: L24609.

Tsunogai, S., S. Watanabe, and T. Sato. 1999. Is there a "continental shelf pump" for the absorption of atmospheric $\mathrm{CO}_{2}$ ? Tellus 51B: 701-712.

Vandemark, D., J.E. Salisbury, C.W. Hunt, S.M. Shellito, J.D. Irish, W.R. McGillis, C.L. Sabine, and S.M. Maenner. 2011. Temporal and spatial dynamics of $\mathrm{CO}_{2}$ air-sea flux in the Gulf of Maine. J. Geophys. Res. 116: C01012.

Walsh, J.J. 1988. On the Nature of Continental Shelves. San Diego: Academic Press.

Wang, S.L., C.T.A. Chen, G.H. Hong, and C.S. Chung. 2000. Carbon dioxide and related parameters in the East China Sea. Cont. Shelf Res. 20: 525-544.

Wiseman, W.J., N.N. Rabalais, R.E. Turner, S.P. Dinnel, and A. Macnaughton. 1997. Seasonal and interannual variability within the Louisiana coastal current: stratification and hypoxia. J. Mar. Syst. 12: 237-248.

Wisser, D., B.M. Fekete, C.J. Vörösmarty, and A.H. Schumann. 2010. Reconstructing 20th century global hydrography: a contribution to the Global Terrestrial Network-Hydrology (GTN-H). Hydrol. Earth Syst. Sci. 14: 1-24.

Woodwell, G.M., P.H. Rich, and C.A.S. Hall. 1973. Carbon in estuaries, In: Woodwell, G.M., and Pecan, E.V. (eds.), Carbon and the Biosphere. Springfield, VA: Atomic Commission.

Zhai, W., and M. Dai. 2009. On the seasonal variation of air - sea $\mathrm{CO}_{2}$ fluxes in the outer Changjiang (Yangtze River) Estuary, East China Sea. Mar. Chem. 117: 2-10.

Zhu, W., Q. Yu, Y.Q. Tian, R.F. Chen, and G.B. Gardner. 2011. Estimation of chromophoric dissolved organic matter in the Mississippi and Atchafalaya river plume regions using above-surface hyperspectral remote sensing. J. Geophys. Res. 116: C02011. 